\title{
Niche construction and theory of agricultural origins. Case studies in punctuated equilibrium
}

\author{
Bernhard Weninger \\ Institute of Prehistory, University Cologne, Köln, DE \\ b.weninger@uni-koeln.de
}

\begin{abstract}
In contemporary archaeological and anthropological research, the domestication of plants and animals in the Near East during the Early Holocene is alternatively interpreted as an overall slow and gradual, or as a rapid process. The present reanalysis of published archaeobotanical and archaeozoological data shows that the wild-domesticate-transition (WDT) was indeed initially slow (millennial scale), but terminated at $10.2 \pm 0.2 \mathrm{ka}$ cal BP with an abrupt switch to herding and agriculture. The abruptness of WDT can be understood as due to amplification under positive feedback conditions (resonance) of some few biological and social factors, primarily the short and longdistance transport of domesticates, in conjunction with a synchronous, abrupt climatic switch to higher precipitation.
\end{abstract}

KEY WORDS - punctuated equilibrium; Neolithisation; cereal domestication; animal domestication; darwinism; complex system theory; palaeoclimatology

\section{Konstrukcija niše in teorija o izvorih poljedelstva. Študijski primer $v$ modelu prekinitve ravnovesja}

IZVLEČEK - Sodobne arheološke in antropološke raziskave razlagajo pojav kultiviranih rastlin in udomačenih živali na Bližnjem vzhodu v času zgodnjega holocena bodisi kot počasen in postopen bodisi kot hiter proces. Pričujoča ponovna analiza objavljenih arheobotaničnih in arheozooloških podatkov kaže, da je bil prehod med divjimi in domačimi vrstami (ang. kr. WDT) sprva počasen (na nivoju tisočletij), ki pa se je končal v času ok. $10.2 \pm 0.2$ ka cal BP z nenadnim preklopom na živinorejo in poljedelstvo. Nenadnost tega prehoda lahko razumemo kot posledico ojačenja pri nekaterih bioloških in družbenih dejavnikih, predvsem pri transportu udomačenih vrst na kratkih in dolgih razdaljah, do katerih je prišlo zaradi pozitivnih povratnih razmer (resonanca) skupaj z nenadno klimatsko spremembo, povezano z intenzivnimi padavinskimi obdobji.

KLJUČNE BESEDE - model prekinjenega ravnovesja; neolitizacija; kultiviranje žit; udomačitev živali; darvinizem; teorija kompleksnih sistemov; paleoklimatologija

\section{Introduction}

A central challenge to the theory of agricultural origins (TAO) concerns the integration and joint interpretation of the increasingly large amounts of numeric empirical data made available by participating scientific disciplines, for example, cultural studies, archaeobotany, archaeozoology, plant and animal genetics, radiometric dating, palaeogeography, palaeoclimatology, and others. In a recently published study, Kristen Gremillion et al. (2014) have argued that it may be possible to unify the scientific results pertaining to TAO under the umbrella of neo-Darwinian evolutionary theory. To the same topic, Kim 
Sterelny and Trevor Watkins (2015.673) propose that it would be advantageous to extend the application of niche construction theory (NCT) in archaeological research if it were extended to accommodate the more complex social worlds of human societies in the form of a cognitive-cultural (or informational) niche. Moving in the same direction, in the present paper it is suggested that a particular extension of NCT, namely Punctuated Equilibrium (Gould, Eldredge 1993), can be observed in the archaeological record for Early Neolithic plant cultivation and animal domestication, despite its high degree of ${ }^{14} \mathrm{C}$-related chronological noise.

Parallel to the rapid expansion of empirical data and knowledge pertaining to the archaeological, palaeogenetic, and socioecological context of Early Neolithic plant cultivation and animal domestication in the Near East, what we observe in the archaeological theory of agricultural origins (TAO) - according to Gremillion et al. (2014) - is an increase in particularism and a major retreat from generalising anthropological theory. The authors propose that this change in research traditions may be due to the wealth of archaeological records, the very richness of which appears to "dampen the appeal of general explanations for the transition to agriculture" (Gremillion et al. 2014.6171), and which has the effect of producing an "increasingly critical attitude of archaeologists towards hypothetico-deductive science". According to the authors, this scientific disposition would lead to a proliferation of research in favour of "historical narratives that highlight local events and processes and downplay general principles" (ibid.). They propose unifying the different approaches to human agricultural origins under the umbrella of neo-Darwinian evolutionary theory (Gremillion et al. 2014.6176).

Interestingly, a similar repositioning of agricultural theory is envisioned by Sterelny and Watkins (2015), who contend that concepts underlying now widely applied biological niche construction theory (NCT) would also fit the description of the Neolithisation process, if only NCT were extended to encompass the more complex social worlds of human societies in the form of a cognitive-cultural (or informational) niche (Sterelny, Watkins 2015.673). We may abbreviate discussion of these issues by confirming directly that NCT has increasing importance in a variety of disciplines, ranging from anthropology, biology, evolutionary theory, genetics, palaeontology and biological physics, all the way through the alphabet to zoology, and thereby, naturally, for different species of plants and animals, both microscopic and macroscopic, including humans (Gould, Eldredge 1977; 1993; Gould 1989; Jones et al. 1994; Laland et al. 2016; Saltz et al. 2016; Zeder 2016). NCT is equally promising for applications in archaeology, for which purpose even the elementary (unpretentious) renaming of the Neolithic Package as a mobile eco-system that is capable of environmental or climatic habitattracking may help students and researchers alike to achieve a qualitatively better understanding of the complex processes underlying Neolithisation. In the long run, however, quantitative modelling of archaeological NCT appears to be necessary.

\section{Punctuated Equilibrium (PE)}

In the following, let us explore what might happen in archaeological NCT discourse if concepts derived from the neo-darwinian theory of punctuated equilibrium (Gould, Eldredge 1977; 1993; Gould 2007) are taken into consideration. In contrast to classical Darwinian forecasting, the geological record shows not a slow and continuous fossil development ( $\mathrm{gra}$ duation), but instead long periods of stasis with no observable change. Then follows an abrupt switch from one species to the next (punctuation), with no apparent transition. According to Darwin's (and others'), explanation, the geological observation of a seemingly abrupt and quasi-instantaneous origination of new palaeontological species is caused by the notoriously imperfect character of the fossil record due to stratigraphic disturbance, incomplete preservation, and fragmentary research (Gould, Eldredge 1993.223). For PE theory, in contrast, the abrupt origination of species is the result neither of noisy or missing data, nor of an unobserved geographic switch in habitat, but the expected and meaningful consequence of a rapid genetic switch from one species to the next, following the law of natural selection. In a nutshell, most species originate in such brief moments of time, that expected 'transitions' have no apparent manifestation in the geological stratigraphy (Gould 2007).

But how does PE work? As indicated above, many PE related processes are (today) subsumed under what is more commonly called the Theory of Complex Systems (or similar), but I propose we continue to use the term PE. An example from physics would be coulomb excitation, whereby a subatomic particle passes so close to an atomic nucleus that the local disturbance of the electromagnetic field triggers the production of a new particle (Alder, Winther 1958). The key word in this example is disturbance, al- 
though other scientific disciplines might replace it by words such as amplification, bifurcation, psychological or mechanical stress, break in symmetry, genetic bottleneck, or genetic isolation. Hence, in TAO, disturbed equilibrium would be a useful alternative to punctuated equilibrium. In general terms, when a long-stable running system is disturbed, interesting things may happen, and if the change does happen, it will typically happen suddenly (e.g., particle production, formation of ice crystals, Neolithic founder crops (Heun et al. 1997; 2012), Rapid Climate Change, the French Revolution, particle freeze out in cosmology, Neolithisation (this paper), switch in pottery style, North Atlantic thermohaline circulation (Rahmstorf 2002), division-by-zero, and genetic bottleneck (Lucas et al. 2012). If all disturbances were put together in a box (modelled) and compared (quantified) it is quite likely that the strongest disturbance will turn out to be: human agency. This is our first accomplished PE forecasting.

\section{Archaeological examples of punctuated equi- librium}

To continue the (now initialised) archaeological PE thought experiment we must next be unscrupulous enough to replace geological with historical timescales, whereby millions of palaeontological years as in the original case studies by Stephen J. Gould and Niles Eldredge (1993) - are reduced to the few generations (or less) required for prehistoric societal change, even down to the few nanoseconds needed for the molecular reactions of DNA-molecules. But as a reward, the following case studies render some first indication that punctuated equilibrium may also be identifiable in the Neolithisation process, even if initially the concept is seemingly contradictory. But there are many other archaeological studies with PE application (e.g., Kolodny et al. 2015; with references).

In contemporary Neolithisation research, the spread of farming/herding lifestyles from the Near East to Europe is most often described as a slow and continuous process, steered mainly by demographic considerations, which need focus on limitations on otherwise explosive exponential population growth, and whereby many thousands of years are considered necessary for the long-distance transfer of the new lifestyle from the Fertile Crescent through Anatolia to Central Europe. Average speeds are estimated to be in the order of $1 \mathrm{~km} / \mathrm{yr}$, with small variations, $\max \pm 30 \%$ (e.g., Ammerman, Cavalli-Sforza 1971; Pinhasi et al. 2005). Observed deviations from such slow and gradual Neolithisation are understood to be noteworthy exceptions, which therefore require exceptional explanation. This is evident in the formulation of research questions such as "why did the expansion of the Körös-Starčevo culture stop in the centre of the Carpathian Basin?" (Kertész, Sümegi 2001).

A further whispering of the possible existence of a very different, namely rapid, PE-type of Neolithisation is manifest in the names chosen for a number of farming dispersion models, such as leapfrog Neolithisation (Arnaud 1982), late escape (Schoop 2005), floodplain hopping (van Andel, Runnels 1995), and - most clearly - in arrhythmic dispersal (Guilaine 2001; 2013). Admittedly, nomen est omen is not an entirely convincing argument. Perchance a better example would be the Neolithisation of the British Isles, which was established around $4000 \mathrm{cal} \mathrm{BC}$, within less than 200 years (Bayliss et al. 2007; Whittle et al. 2008; Collard et al. 2010). In this case, it is the transition from the Mesolithic to the Neolithic that would appear punctuated (P), and the punctuation $P$ is both preceded and followed by extended periods of cultural equilibrium (E); first, a long Mesolithic-E, then a long Neolithic-E, but with only a little time in between for changes in culture and economy, perhaps a few human generations. The occurrence of rapid cultural PE on the British Isles around $4000 \mathrm{cal} \mathrm{BC}$ is well-supported by vast numbers of ${ }_{14}^{14}$-dates. Although rapid Neolithic demographic expansion does not only follow from the size of the ${ }^{14} \mathrm{C}$-database, both are in perfect agreement with PE extension of NCT. We note with interest that the long-term success of Neolithic stasis on the British Isles has been called into question by Chris J. Stevens and Dorian Q. Fuller (2012), who postulate a failure of plant cultivation and temporary switch to pastoralism, if only based on missing data in the radiocarbon record. There is critical response by Rosie R. Bishop (2015).

Neither would the postulated overlap of European Neolithic 'cultures' based on arguments to replace the old pottery-style definitions with new ${ }^{14} \mathrm{C}$-derived concepts (Manning et al. 2014), provide convincing anti-PE arguments. According to Katie Manning et al. (2014.1065), the "...resulting [14C-statistical] analysis gives a new and more accurate description of the duration and intensity of European Neolithic cultures". In my view, the opposite is the case; namely, the traditional sequence of European Neolithic cultures, with its (true) abrupt and geographically widespread, indeed often block-wise switch from one 
pottery style to the next (e.g., LBK $\rightarrow$ Stichbandkeramik $\rightarrow>$ Rössen $\rightarrow$ Michelsberg), complies entirely with PE-forecasting. Furthermore, the ${ }^{14} \mathrm{C}$-overlap used by Manning et al. (2014) to motivate the introduction of a new, statistical definition of culture has little relation, if any, to any previous discourse on how to define archaeological culture (e.g., Lüning 1972). It is due to the inherent noisiness of underlying archaeological ${ }^{14} \mathrm{C}$-data (e.g., Breunig 1987). This readily explains the observed, largely Gaussianshape (white noise) of calibrated summed ${ }^{14} \mathrm{C}$-distributions. Indeed, the noisiness of archaeological data is so overwhelming that the calibrated distributions (Manning et al. 2014.Figs. 4-6) show little of the otherwise regularly observable distortion due to the non-linear shape of the ${ }^{14} \mathrm{C}$-age calibration curve. In comparison, the punctuated peak production (basically a division-by-zero problem) that is induced by theoretically motivated but experimentally invalidated Bayesian normalisation (Weninger et al. 2011; 2015) remains all the more visible in the calibrated age distributions. Together with their wide Gaussian shape, these two observations imply that the graphs show (largely) noise. What does deserve further attention is the question why the abrupt changes in Neolithic pottery style observed so often in finds are so clearly compatible with PE rules.

A much larger scale PE-NCT application is demonstrated for the spread of farming from the Near East into the Aegean along established Epipalaeothic coastal networks in the eastern Mediterranean ( $c f$. Cilingiroğlu 2010; Reingruber 2011; Brami, Heyd 2011; Horejs et al. 2015). The radiocarbon dates indicate a simultaneous (decadel-scale) Neolithisation of the Turkish west coast and of the Peloponnese, which my colleague Lee Clare and I have attributed to climatic habitat-tracking due to widespread cold winter Rapid Climate Change (RCC) conditions, with a similar incentive presumably underlying the long-distance movement from the Near East along the Turkish south coast into the Aegean (Weninger et al. 2014; Clare, Weninger 2014; 2016; Clare 2016). Recently, bio-climatically optimised choice of landscapes by Neolithic farming communities is also reported for the Balkans, both for the start and end of the RCC-synchronous Neolithisation of the circum-Aegean landscapes (8.6-8.0 ka cal BP), and this we may consider evidence of Neolithic climatic engineering, in any case of careful (simultaneous) ecological and cultural niche selection (Krauß et al. 2014; 2017). High dispersion speeds are also reported for the land-based spread of farming out of the Aegean into the Pannonian Basin (Weninger et al. 2014), as well as for coa- stal movements in the Western Mediterranean (Isern et al. 2017) as far as Morocco (Linstädter et al. 2012; 2016). Again, it is primarily the timing of these transitions that indicate PE-type Neolithisation. Conversely, beyond confirming PE-type Neolithisation, these findings immediately challenge the conclusion of Neus Isern et al. (2017.897), that speeds of $\sim 2500 \mathrm{~km}$ in $300 \mathrm{yrs}$ can be achieved only by sea travel, and not overland. This perception clearly relies on the validity of slow and continuous wave-of-advance-type dispersion, such that (slow) overland routes would be the predictable norm and (fast) sea travel the specific exception. Neolithic wave-of-advance dispersion is clearly at odds with PE-type modelling, for which both routes are equally fast. Hence, although yet further confirmation of the quite astonishing speeds of Neolithic dispersion would be welcome, these examples demonstrate the potential of PE-forecasting. In general terms, from the viewpoint of NCT, we may expect only a few exceptions from the otherwise general rule that, to be successful (in a Darwinian sense), major changes in both economic and cultural resources should be as rapid as possible.

Now turning to the theory of agricultural origins (TAO), it would follow from PE that the time required for the Near-Eastern transition from wild to domesticated (plants and animals) is likely to be short (i.e. punctuated), and unlikely to be extended (i.e. protracted). What complicates matters is the large number of participating units (cereals, legumes, sheep, goat, cattle, humans etc.), as they are intricately interconnected within a complex eco-system (e.g., Gopher et al. 2001; Jones et al. 1994; Laland et al. 2016). Nevertheless, based on observed complexity alone, we should not automatically concede that the WDT was necessarily protracted (e.g., Purugganan, Fuller 2011; Fuller et al. 2012; Maeda et al. 2016; cf. significant critique by Heun et al. 2012). An open question is, do we really observe the postulated protracted adaptation of domesticated plants and animals? Namely, given that corresponding timescales are essentially all based on ${ }^{14} \mathrm{C}$-data, and knowing of the extreme noisiness of such data, we might instead become immediately (very) suspicious as to the quality of the observations. Some large (but difficult to isolate) part of the observed slowness in the archaeological record is surely to be caused by the artificial spread of ${ }^{14} \mathrm{C}$-data, $e . g$., due to stratigraphic disturbance, sample contamination, chance statistical reasons, age-distortion due to the non-commutative character of the calibration curve etc. Strictly speaking, with much of the ${ }^{14} \mathrm{C}$-data under study now half 
a century old, we would like to disregard the data altogether. At first glance, the best procedure to separate the signal from the noise would indeed be to apply some strong taphonomic and statistical filter to the ${ }^{14} \mathrm{C}$-data. This was the analytical method applied to the ${ }^{14} \mathrm{C}$-data by Pascal Flohr et al. (2015) in search of the potential impact of the 8.2 and 9.2 ka cal BP cold winter climatic events on the Near Eastern Neolithic. Unfortunately, and as Flohr et al. (2015) correctly observe, even the strongest filtering of available ${ }^{14} \mathrm{C}$-data does not itself provide a straightforward 'yes/no' answer to the research question in hand, concerning potential social climate impact. It is also unfortunate that the postulated social resilience to climate change does not even theoretically follow from its non-identification (Flohr et al. 2015). A more promising approach lies in dedicated climate-archaeological fieldwork (e.g., Zielhofer et al. 2012).

In the following, we continue our previous WDTstudies with subordinate further consideration of the available ${ }^{14} \mathrm{C}$-data, which have already undergone sufficient analysis (e.g., Weninger et al. 2009; Asouti, Fuller 2013; Borrell et al. 2015). Instead, let us have a fresh look at the remarkable coincidence of the WDT with the previously identified major increase in precipitation levels in large parts of the Near East at around $10.2 \mathrm{ka}$ cal BP. This is now possible in the context of newly available climate records, particularly, the Lake Neor Titanium (dust) record (Sharafi et al. 2015). As previously noted (Weninger et al. 2009), within dating errors of approx. $\pm 100 \mathrm{yrs}(68 \%)$, the earliest use of genetically changed cereals coincides perfectly with both an abrupt 50-metre rise in Dead Sea levels, as well as the onset of Sapropel S1. On the archaeobotanical side, the synchronism is based on cereal data from a reasonable number of archaeological sites $(\mathrm{N}=44)$, with cereal inventories classified as 'wild' $(\mathrm{N}=8)$, 'domesticated' $(\mathrm{N}=31)$ and 'unclear' $(\mathrm{N}=5)$ by Mark Nesbitt (2002). In the meantime, and based on significantly extended archaeobotanical and ${ }^{14} \mathrm{C}$-radiometric datasets, Eleni Asouti and Dorian Q. Fuller (2013) have come to an entirely different conclusion, which is that the transition from the use of wild to domesticated plants was an extended (protracted) process, with a time-span in the order of thousands of years. This is curious, since statistical theory would normally predict a shortening of any time-span based on a refined set of $14 \mathrm{C}$-data, and not a lengthening (and least not by a factor $\sim 10$ according to Asouti, Fuller 2013 in comparison to Nesbitt 2002 and Weninger et al. 2009).

\section{Methods and data}

We will return below to the arguments supporting rapid (decadel-scale) WDT versus slow and gradual (millenial scale) development. To run this comparison required the expansion of available CalPal-software, and in particular the development of a new CalPal-dialog (called Multiclimate Composer), as described in detail in the Appendix, available online at http://dx.doi.org/10.4312/dp.44.1.

\section{Results}

Utilising for the first time the new CalPal Multiclimate Composer, Figure 1 and Figure 2 provide a graphic representation of published archaeobotanical (here: barley), archaeozoological (here: cattle) and climatic data (selected regions). In my view, although non-expert in the analysis of archaeobiological data, the records would support the statements listed below (Points 1-8). Note that these results are based on (further) critical interpretation of the large amounts of archaeological ${ }^{14} \mathrm{C}$-data that were already critically assembled and statistically analysed by the authors of the respective botanical and zoological data (Asouti, Fuller 2013; Arbuckle et al. 2016). Additionally, I am applying here an extended mode of record interpretation, whereby it is deemed necessary to read the given ( $68 \%$ confidence) chronological time-spans of the archaeological settlements in a specific manner:

(A) The time-spans provided for sites that contain domesticated cereals (here exemplified for domesticated barley) are interpreted as termini post quem for the earliest use of cereals. Hence, in Figure 1C, the true dates for the introduction of domesticated barley must range on the left (older) side of the (blue) set of site intervals.

(B) The time-spans provided for sites that contain wild cereals (here exemplified for wild barley) are interpreted as termini ante quem for the earliest (possible) use of domesticated cereals. Hence, in Figure 1E, the true dates for the introduction of domesticated barley must range on the right (younger) side of the (green) set of site intervals.

(C) The time-spans provided for sites that contain 'partially domesticated' cereals (here exemplified for barley) are indecisive in terms of further refining the already given age and length of the WDT (Weninger et al. 2009 - using data of Nesbitt 2002). The archaeobotanical refinement by Asouti and Fuller (2013) of introducing 'partially domesticated' cereals is 


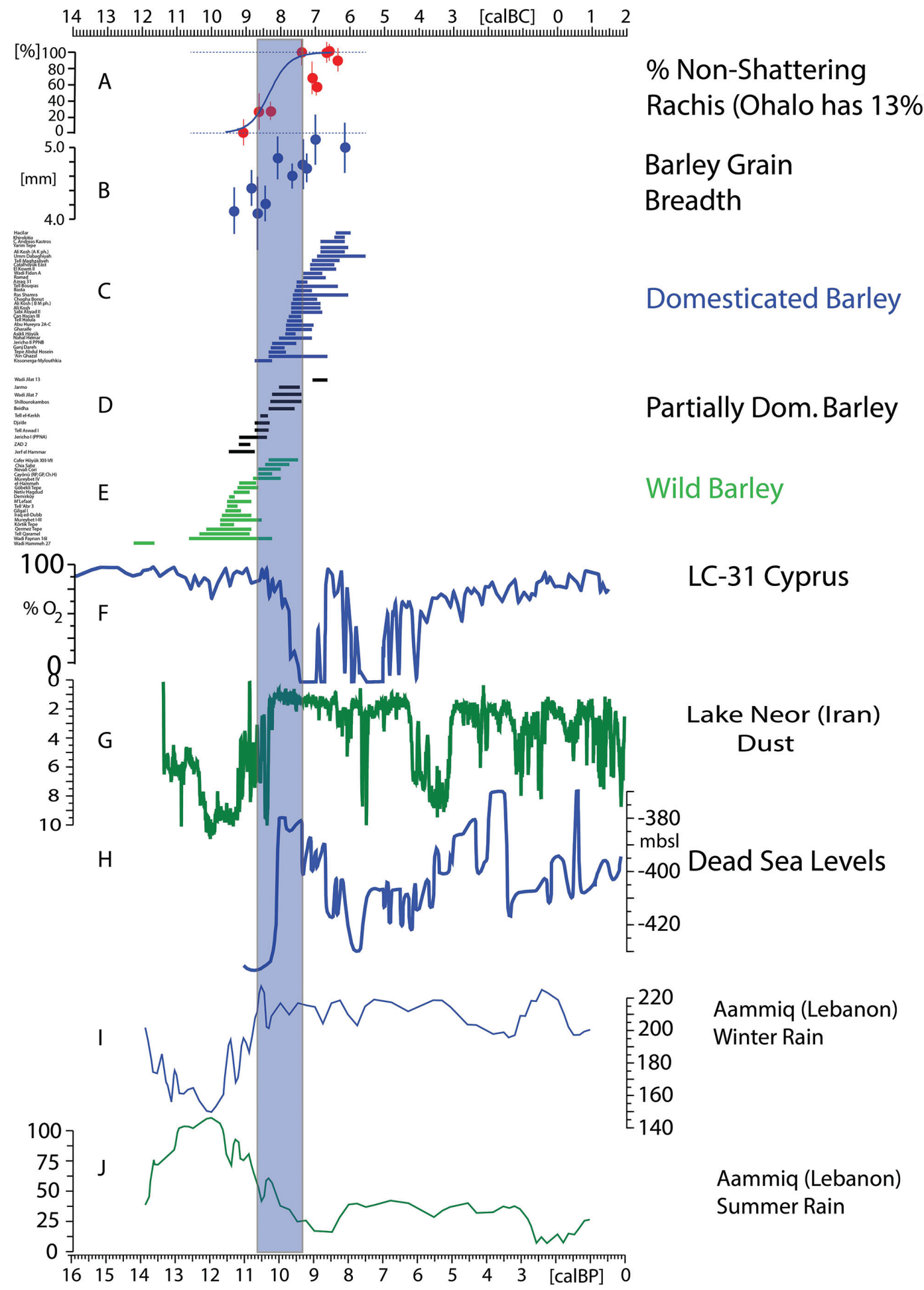

Fig. 1. Selection of climatic and archaeobotanical records, drawn with the CalPal Multiclimate Dialog (Fig. 4), edited with Adobe Illustrator ${ }^{\odot}$.

Sources: $A$ Asouti, Fuller 2013 (ebda. Fig. 4: A Barley); B Asouti, Fuller 2013 (ebda. Fig. 5: grain breadth); $C$ Asouti, Fuller 2013 (ebda. Tab. 3: sites with barley and D-prefix); D Asouti, Fuller 2013 (ebda. Tab. 3: sites with barley and d-prefix); E Asouti, Fuller 2013 (ebda. Tab. 3: sites with wild barley); F Marine Core LC31 (Cyprus) (Schmiedl et al. 2010), Benthic Foraminifera Oxygen Index; G Lake Neor (Iran) Dust Record (Sharifi et al. 2015); H Dead Sea Levels (Migowski et al. 2006); I Aammiq (Lebanon) (Cheddadi, Khater 2016); J Aammiq (Lebanon), Summer Rain (Cheddadi, Khater 2016).

Note: ${ }^{14}$ C-based site-spans (68\%) are taken unchanged from Asouti and Fuller (2013). The shaded area $10.2 \pm 0.2 \mathrm{ka}$ cal BP (68\%) indicates the beginning of Sapropel S1 according to Schmiedl et al. (2010), which is likely also to cover the WDT (visual analysis). 


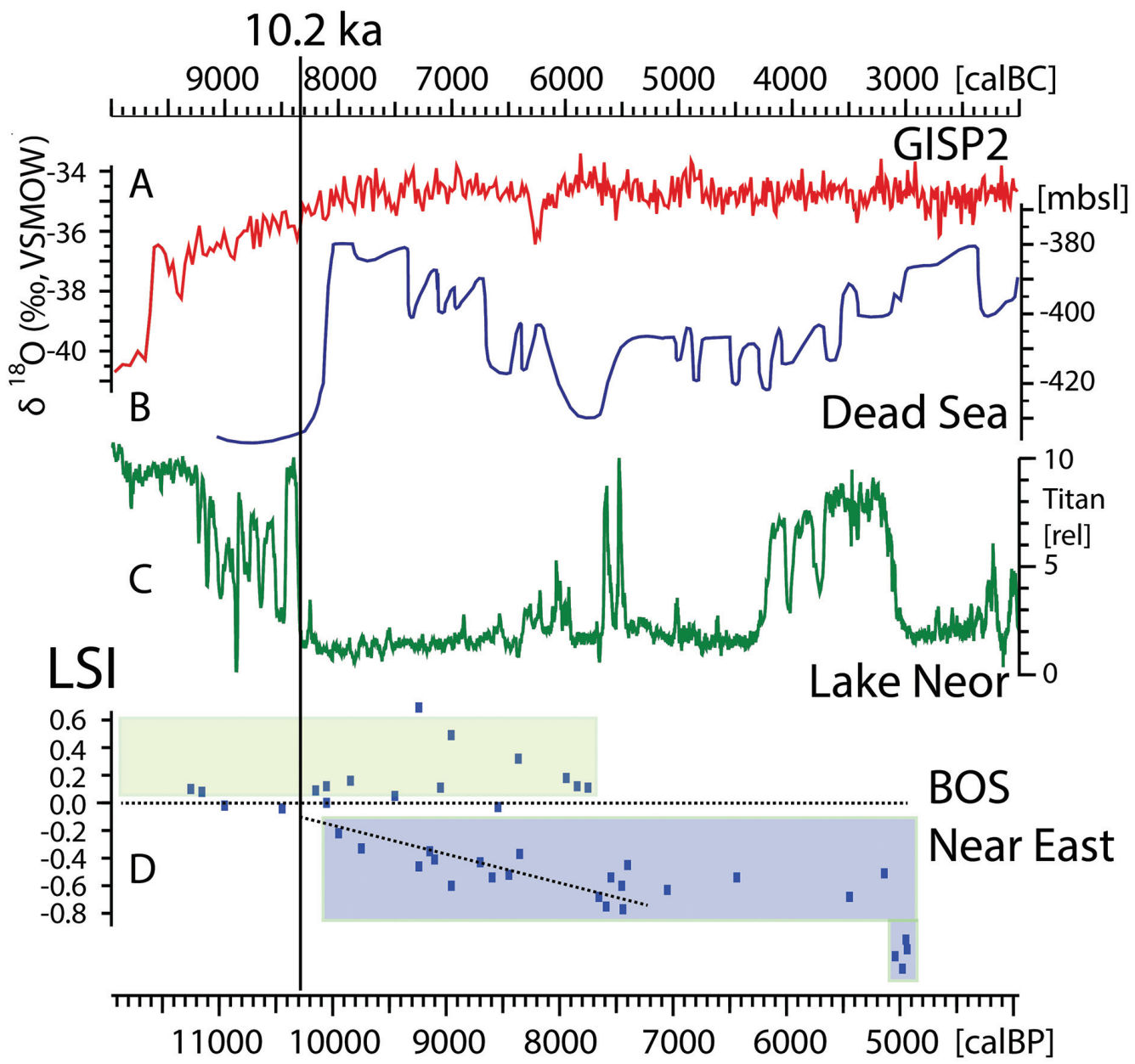

Fig. 2. Selection of climatic records and comparison with LSI (Logarithmic size indices) for cattle bone from Early Holocene archaeological sites; graph drawn with CalPal Multiclimate Dialog (Fig. 5) and edited with Adobe Illustrator (C. A Greenland GISP2 ice-core stable oxygen isotopes $\delta 180$ (Grootes et al. 1993) shown to illustrate the long timespan (i.e. stasis) between Younger Dryas (end $\sim 11.6 \mathrm{ka}$ cal BP) and WDtransition at 10.2 $\pm 0.2 \mathrm{ka}$ cal BP (vertical line); B Dead Sea Lake Level (Migowski et al. 2006); C Lake Neor (Iran) Dust Record (Sharifi et al. 2015); D LSI: Logarithmic Size Index for Bos. LSI-values > 0 (wild); LSI-values $<0$ (domesticated). Data digitised from Arbuckle et al. (2016. Fig. 3) with minor age-corrections. Dashed line: Visual extrapolation of LSI-data (values <0) back in time to identify (approx.) timepoint of earliest cattle-domestication (near to $10.2 \pm 0.2 \mathrm{ka}$ cal BP).

nonetheless helpful in identifying promising archaeological sites for further studies.

Accepting that available ${ }^{14} \mathrm{C}$-data are mostly too imprecise to support further modelling, in reward, we gain freedom in our ability to make generalising statements about the theory of agricultural origins, as advised by Gremillion et al. (2014). In the present paper, these generalising statements are as follows:

(1) The introduction of domesticated cereals in the Near East was a rapid and abrupt process for which a maximum time-span of $\sim 1000 \mathrm{yrs}(\mathrm{p}=95 \%)$ is presently recognisable in the ${ }^{14} \mathrm{C}$-data. Due to the wellknown highly distributive properties of historical ${ }^{14} \mathrm{C}$-data, the process itself is likely to be significantly shorter, in the order of 20-30 years (max. 200 years) as experimentally demonstrated for wild wheat and barley (Hillman, Davies 1990). Since the precise date and time-span of the WDT remain unknown, and also to emphasise their derivation from punctuated equilbrium (i.e. utiliding a specific theory of evolution), in the following we use the term 'punctuated' to denote a value of 0-200 years.

(2) The punctuated transition from wild to domesticated cereals occurred at $10.2 \pm 0.2 \mathrm{ka}$ cal BP (barley: Fig. 1; other species $c f$. data in Asouti, Fuller 2013).

(3) The punctuated transition from wild to domesticated animals occurred at $10.2 \pm 0.2 \mathrm{ka}$ cal BP (cattle: Fig. 2; other species $c f$. data in Arbuckle et al. 2016). 
(4) Following an extended period of cultural and biological stasis during and following the Younger Dryas (Bar-Yosef 1989; 1998; Haldorsen 2011), the WDT is coincident with a major climatic switch to higher levels of precipitation (winter rain). This quite remarkable climatic background to the WDT is observable as a sharp transition to higher levels of precipitation around $10.2 \pm 0.2 \mathrm{ka}$ cal BP in a large number of terrestrial records, including Lake Neor (Iran), Aammiq (Lebanon), at high resolution (U/Th) in Jeita Cave (Lebanon), as well as in many Eastern Mediterranean marine records (Schmiedl et al. 2010).

(5) The age-value of $10.2 \pm 0.2 \mathrm{ka}$ cal BP common to these archaeobiological and climatic events and processes is itself synchonous (within given dating limits) with earliest farming communities in Central Anatolia, such as at Aşikli Hüyük (Stiner et al. 2014), as well as in Iran, in particular at Ganj Dareh (Zeder, Hesse 2000). Additional evidence of a punctuated beginning of farming/herding at around $10.2 \pm 0.2 \mathrm{ka}$ in Iran can be seen in the remarkable increase in the number of radiocarbon dates that are classified as 'Neolithic' in the CalPal-database ( $c f$. Appendix, available online at http://dx.doi.org/10.4312/dp.44.1). The temporal development of Iranian Neolithic ${ }^{14} \mathrm{C}$ data runs closely parallel with Sapropel S1 as well as with the dust record from Lake Neor (Fig. 5, lowest record), for reasons yet to be deciphered. The Iran/Neolithic ${ }^{14} \mathrm{C}$-data $(\mathrm{N}=362)$ is imported here with no filter applied from the CalPal ${ }^{14} \mathrm{C}$-database. The ${ }^{14} \mathrm{C}$-data in the database of Flohr et al. (2015) shows essentially the same structure, with or without filtering (e.g., long/short-lived samples, high/low measuring precision, modern/old excavations etc.). This motivates further hydroclimatic-archaeological studies of the Iranian Neolithic, but is not our immediate topic.

In conclusion, the system disturbance necessary to understand PE-type Neolithisation is presumably to be found in (A) the self-pollinating properties of the Near Eastern founder cereals. This property makes the movement of domesticated plants beyond $\sim 50 \mathrm{~m}$ dependent on human agency (Honne, Heun 2011; Heun et al. 2012), and/or (B) in genetic isolation of mixed W/D-cereals due to the colonisation of Cyprus and (amplifying) back-transport of domesticated cereals to the mainland (Lucas et al. 2012), and/or (C) abrupt changes in precipitation that occurred around $10.2 \pm 0.2 \mathrm{ka}$ cal BP (Fig. 1); and/or (D) the occurrence of a brief (decadel-scale) cold-winter RCCextreme event at around $10.2 \pm 0.2 \mathrm{ka}$ calBP (BarYosef 1986; Weninger et al. 2009; Borrell et al.
2015), but with presumably a different impact in the northern and southern Levant (Cheng et al. 2015), and/or (E) the major geographic dispersal of the Neolithic at around $10.2 \pm 0.2 \mathrm{ka}$ calBP into Central Anatolia and Iran that would itself have presumably caused the (further) genetic isolation of WD-transitional plants and animals (cf. Brandolini et al. 2016); as well as, most importantly, (F) short- and long-distance exchange/trade in domesticates, as proposed by Heun et al. 2012), and finally, (G) an amplifying combination of factors (A-F).

\section{Outlook for quantitative modelling}

My personal preference for modelling the WDT is (G): the PE auto-amplification description. This is because, if confirmed, any attempted larger-scale mathematical study would presumably have a good start already by application of the well-known and widely applicable harmonic resonance equations (for different frequencies and dampening). In agreement with proposals by Sterelny and Watkins (2015), surely the most important causal parameter in the rapid WDT is human agency, which could be modelled as a central driving factor acting under resonance conditions within a wider network of natural (bioclimatic) processes. The factors leading to WD-resonance might have to be attenuated (dampened) to some extent, e.g., to allow for continued human selection of wild cereals during and followed the WDT. This would introduce an additional temporal spread of the rapid transition, yet to be quantified (presumably multi-decadel scale), on top of the (conservative) 200-year estimate by Gordon C. Hillman and M. Stuart Davies (1990), but even then the width of transition would be well-covered by the statistical interval of $\pm 0.2 \mathrm{ka}(68 \%)$, i.e. length 1000 years $(>95 \%)$ as shown (graphically) in Fig. 1 for the WDT. Presumably, there exist other cultural and biological niche-related phenomena yet to be discovered that show resonance amplification. I could also imagine that the application of resonance equations would be an interesting alternative to the use of stepwise truncated exponential or logistic growth functions in archaeological (or other) applications of punctuated equilibrium, but this surely depends very much on application (e.g., Kolodny et al. 2015).

\section{Conclusions}

In this paper the suggestion is made that Punctuated Equilibrium (Gould, Eldredge 1993) can be observed in the archaeological and archaeobiological record for the Early Holocene WDT in the Near East, 
despite its high degree of chronological noise. This idea is derived from a combined graphic visualisation of large quantities of palaeobiological, climatological, and archaeological data. From the viewpoint of Nonlinear System Theory, it appears possible to describe (as well as understand) the extreme rapidity of the WDT as due to amplification with positive feedback for a small number of reasonably explicit causal factors. With such an approach, it might be possible to decide whether the WDT-transition follows deterministic (strictly forecastable) or chaotic (non-predictable) laws. A more general application of PE-type Neolithisation in the Theory of Agricultural Origins is indicated by case studies relating to later phases of Neolithic Dispersion.

\section{ACKNOWLEDGEMENTS}

My special thanks go to Harvey Weiss, who made me aware, as so often, of fascinating research I would have otherwise presumably not encountered, in this case by Stephen Jay Gould and Niles Eldredge.

\section{References}

Alder K., Winther A. 1958. The Theory of Coulomb Excitation of Nuclei. Physical Review 91: 237-238.

Ammerman A. J., Cavalli-Sforza L. L. 1971. Measuring the rate and spread of early farming in Europe. Man 6: 784688.

Arbuckle B. S. and 22 co-authors. 2014. Data Sharing Reveals Complexity in the Westward Spread of Domestic Animals across Neolithic Turkey. PLOS ONE 6: e99845.

Arbuckle B. S., Price M. D., Hongo H. and Öksüz B. 2016. Documenting the initial appearance of domestic cattle in the Eastern Fertile Crescent (northern Iraq and western Iran). Journal of Archaeological Science 72: 1-9.

Arnaud J. M. 1982. Le Néolithique ancien at processus de néolithisation dans le sud du Portugal. In R. Montjardin (ed.), Le Néolithique Ancien Méditerranéen: Actes du Colloque International de Préhistoire, Montpellier 1981. Archéologie en Languedoc No. Special 1982. Fédération Archéologique de l'Hérault. Sète: 29-48.

Asouti E., Fuller D. Q. 2013. A Contextual Approach to the Emergence of Agriculture in Southwest Asia. Current Anthropology 54(3): 299-345.

Bar-Yosef 0. 1989. The PPNA in the Levant - An Overview. Paléorient 15(1): 57-63.

1986. The walls of Jericho: an alternative interpretation. Current Anthropology 27: 157-162.

1998. The Natufian Culture in the Levant, Threshold to the Origins of Agriculture. Evolutionary Anthropology 6(5): $159-177$
Bayliss A., Bronk Ramsey C., van der Plicht J. and Whittle A. 2007. Bradshaw and Bayes: towards a timetable for the Neolithic. Cambridge Archaeological Journal 17(1), supplement: 1-28.

Benz M., Coşkun A., Hajdas I., Deckers K., Riehl S., Alt K., Weninger B. and Özkaya V. 2012. Methodological Implications of the new radiocarbon dates from the Early Holocene site of Körtik Tepe, Southeast Anatolia. Radiocarbon 54(3-4): 291-304.

Bishop R. R. 2015. Did Late Neolithic farming fail or flourish? A Scottish perspective on the evidence for Late Neolithic arable cultivation in the British Isles. World Archaeology 47: 834-855.

Borrell F., Junno A. and Barceló J. A. 2015. Synchronous Environmental and Cultural Change in the Emergence of Agricultural Economies 10,000 Years Ago in the Levant. PLOS ONE 10(8): 1-19.

Brami M., Heyd V. 2011. The origins of Europe's first farmers: the role of Hacilar and Western Anatolia, fifty years on. Prähistorische Zeitschrift 86(2): 165-206.

Brandolini A., Volante A. and Heun M. 2016. Geographic differentiation of domesticated einkorn wheat and possible Neolithic migration routes. Heredity 117: 135-141.

Breunig P. 1987. ${ }^{14}$ C-Chronologie des vorderasiatischen, südost- und mitteleuropäischen Neolithikums. Fundamenta Reihe A, Band 13. Böhlau Verlag. Köln.

Cheddadi R., Khater C. 2016. Climate change since the last glacial period in Lebanon and the persistance of Mediterranean species. Quaternary Science Reviews 150: 146-157. 
Cheng H., Sinha A., Verheyden S., Nader F. H., Li X. L., Zhang P. Z., Yin J. J., Yi L., Peng Y. B., Rao Z. G., Ning Y. F. and Edwards R. L. 2015. The climate variability in northern Levant over the past 20,000 years. Geophysical Research Letters 42: 8641-8650. doi: 10.1002/2015GL065 397

Çilingiroğlu C.. 2010. The Appearance of Impressed Pottery in the Neolithic Aegean and its Implications for Maritime Networks in the Eastern Mediterranean. Turkish Academy of Sciences Journal of Archaeology 13: 9-22.

Clare L. 2016. Culture Change and Continuity in the Eastern Mediterranean during Rapid Climate Change. Assessing the vulnerability of Late Neolithic communities to a "Little Ice Age" in the seventh millennium cal B.C. Kölner Studien zur Prähistorischen Archäologie 7. Verlag Marie Leidorf. Köln.

Clare L., Weninger B. 2014. Absolute Chronology and Rapid Climate Change in Central and West Anatolia. In M. Özdoğan, N. Başgelen and P. Kuniholm (eds.), The Neolithic in Turkey. Vol. 6. 10500-5200 BC: Environment, Settlement, Flora, Fauna, Dating, Symbols of Belief, with Views from North, South, East, and West. Archaeology \& Art Publications. Istanbul: 1-65.

2016. Early Warfare and its Contribution to Neolithisation and Dispersal of Neolithic Lifeways of First Farming Communities in Anatolia. In M. Reindel, K. Bartl, F. Lüth and N. Benecke (eds.), Palaeoenvironment and the Development of Early Settlements. Studien aus den Forschungsclustern des Deutschen Archäologischen Instituts. Cluster 1, Band 14. Rahden/Westf.: 29-49.

Collard M., Edinborough K., Shennan S. and Thomas M. G. 2010. Radiocarbon evidence indicates that migrants introduced farming to Britain. Journal of Archaeological Science 37(4): 866-870.

Flohr P., Fleitmann D., Matthews R., Matthews W. and Black S. 2015. Evidence of resilience to past climate change in Southwest Asia: Early farming communities and the 9.2 and 8.2 ka events. Quaternary Science Reviews: http:// dx.doi.org/10.1016/j.quascirev.2015.06.022

Fuller D. Q., Asouti E. and Purugganan M. D. 2012. Cultivation as slow evolutionary entanglement: Comparative data on rate and sequence of domestication. Vegetation History and Archaeobotany 21(2): 131-145.

GEBCO (General Bathymetric Chart of the Oceans) 2017. http://www.gebco.net/about_us/overview/

Gopher A., Abbo S. and Lev-Yadun S. 2001. The "when", the "where" and the "why" of the Neolithic Revolution in the Levant. Documenta Praehistorica 28: 49-61.
Gould S. J. 1989. Punctuated equilibrium in fact and theory. Journal of Social and Biological Structures 12: 117136.

\section{Punctuated Equilibrium. Belknap Press.}

Gould S. J., Eldredge N. 1977. Punctuated Equilibria: The Tempo and Mode of Evolution Reconsidered. Paleobio$\operatorname{logy}$ 3: 115-151.

1993. Punctuated equilibrium come of age. Nature 366: 223-227.

Gremillion K. J., Barton L. and Piperno D. R. 2014. Particularism and the retreat from theory in the archaeology of agricultural origins. Proceedings of the National Academy of Sciences of the USA 111 (17): 6171-6177.

Grootes P. M., Stuiver M., White J. W. C., Johnsen S. and Jouzel J. 1993. Comparison of oxygen isotope records from the GISP2 and GRIP Greenland ice core. Nature 366: 552-554.

Guilaine J. 2001. La diffusion de l'agriculture en Europe: une hypothese arythmique. Zephyrus 53(4): 267-272.

2013. The Neolithic Transition in Europe: some Comments on Gaps, Contacts, Arrhythmic Model, Genetics. In E. Starnini (ed.), Unconformist Archaeology. Papers in honour of Paolo Biagi. British Archaeological Reports IS 2528. Archaeopress. Oxford: 55-64.

Haldorsen S., Akan H., Çelik B. and Heun. M. 2011. The climate of the Younger Dryas a boundary for Einkorn domestication. Vegetation History and Archaeobotany 20: 305-318.

Heun M., Schäfer-Pregl R., Klawan D., Castagna R., Accerbi M., Borghi B. and Salamini F. 1997. Site of einkorn wheat domestication identified by DNA fingerprinting. Science 278: 1312-1314.

Heun M., Abbo S., Lev-Yadun S. and Gopher A. 2012. A critical review of the protracted domestication model for Near-Eastern founder crops: linear regression, log-distance gene flow, archaeological and archaeobotanical evidende. Journal of Experimental Botany 63(12): 4333-4341.

Heun M., Schäfer-Pregl R., Klawan D., Castagna R., Accerbi M., Borghi B. and Salamibi F. 1997. Site of einkorn wheat domestication identified by DNA fingerprinting. Science 278: 1312-1314.

Hillman G. C., Davies M. S. 1990. Domestication rates in wild type wheats and barley under primitive cultivation. Biological Journal of the Linnean Society 39: 39-78. 
Honne B. J., Heun M. 2009. On the domestication genetics of self-fertilizing plants. Vegetation History and Archaeobotany 18: 299-272.

Horejs B., Milić B., Ostmann F., Thanheiser U., Weninger B. and Galik A. 2015. The Aegean in the Early $7^{\text {th Millen- }}$ nium BC: Maritime Networks and Colonization. Journal of World Prehistory 28: 289-330.

Isern N., Zilhão J., Fort J. and Ammerman A. J. 2017. Modeling the role of voyaging in the coastal speed of the Early Neolithic in the West Mediterranean. Proceedings of the National Academy of Sciences 114(5): 897-902.

Jones G. J., Lawton J. H. and Shachak M. 1994. Organisms as ecosystem engineers. OIKOS 69: 373-386.

Kertész R., Sümegi P. 2001. Theories, critiques and a model: Why did the expansion of the Körös-Starčevo culture stop in the centre of the Carpathian Basin? In R. Kertész, J. Makkay (eds.), From the Mesolithic to the Neolithic. Proceedings of the International Archaeological Conference held in the Damjanich Museum of Szolonok, September 22-27, 1996. Archaeolingua. Budapest: 225-246.

Kolodny 0., Creanza N. and Feldman M. W. 2015. Evolutions in leaps: The punctuated accumulation and loss of cultural innovations. Proceedings of the National Academy of Sciences of the USA 112 (49): 3.

Krauß R., Marinova E., De Brue H. and Weninger B. 2017. The rapid spread of early farming from the Aegean into the Balkans via the Sub-Mediterranean-Aegean Vegetation Zone. Quaternary International xxx: 1-18 (in press. https://doi.org/10.1016/j.quaint.2017.01.019).

Krauß R., Elenski N., Weninger B., Clare L., Çakırlar C. and Zidarov P. 2014. Beginnings of the Neolithic in Southeast Europe: the Early Neolithic sequence and absolute dates from Džuljunica-Smărdeš (Bulgaria). Documenta Praehistorica 41: 51-77.

Laland K., Matthews B. and Feldman M. W. 2016. An introduction to niche construction theory. Evolutionary Ecology 30: 191-202.

Linstädter J., Medved I., Solich M. and Weniger G. 2012. Neolithisation process within the Alboran territory: Models and possible African impact. Quaternary International 274: 219-232.

Linstädter J., Broich M. and Weninger B. 2016. Defining the Early Neolithic of the Eastern Rif, Morocco - Spatial distribution, chronological framework and impact of environmental changes. Quaternary International. doi.org /10.1016/j.quaint.2016.07.042
Lucas L., Colledge S., Simmons A. and Fuller D. Q. 2012. Crop introduction and accelerated island evolution: archaeobotanical evidebde from 'Ais Yiorkis and Pre-Pottery Neolithic Cyprus. Vegetation History and Archaeobotany 21: 117-129.

Lüning J. 1972. Zum Kulturbegriff im Neolithikum. Prähistorische Zeitschrift 47: 145-173.

Maeda O., Lucas L., Silva F., Tanno K.-I. and Fuller D. Q. 2016. Narrowing the harvest: Increasing sickle investment and the rise of domesticated cereal agriculture in the Fertile Crescent. Quaternary Science Reviews 145: 226-237.

Manning K., Timpson A., Colledge S., Crema E., Edinborough K. and Shennan S. 2014. The chronology of culture: a comparative assessment of European Neolithic dating approaches. Antiquity 88: 1065-1080.

Migowski C., Stein M., Prasad S., Negendank J. F. W. and Agnon A. 2006. Holocene climate variability and cultural evolution in the Near East from the Dead Sea sedimentary record. Quaternary Research 66: 421-431.

Nesbitt M. 2002. When and where did domesticated cereals first occur in southwest Asia? In R. T. J. Cappers, S. Bottema (eds.), The Dawn of Farming in the Near East. Studies in Early Near Eastern Production, Subsistence, and Environment 6. Ex oriente. Berlin: 113-132.

Pinhasi R., Fort J. and Ammerman A. J. 2005. Tracing the Origin and Spread of Agriculture in Europe. PLOS Biology 3(12): e410. doi:10.1371/journal.pbio.0030410.

Purugganan M. D., Fuller D. Q. 2011. Archaeological data reveal slow rates of evolution during plant domestication. Evolution 65: 171-183.

Rahmstorf S. 2002. Ocean circulation and climate during the past 120,000 years. Nature 419: 207-214.

Reingruber A. 2011. Early Neolithic settlement patterns and exchange networks in the Aegean. Documenta Praehistorica 38: 291-305.

Saltz J. B., Geiger A. P., Anderson R., Johnson B. and Marren R. 2016. What, if anything, is a social niche? Evolutionary Ecology 30: 349-364.

Schmiedl G., Kuhnt T., Ehrmann W., Emeis K.-C., Hamann Y., Kotthoff U., Dulski O. and Pross J. 2010. Climatic Forcing of eastern Mediterranean deep-water formation and benthic ecosystems during the past 22000 years. Quaternary Science Reviews 29: 3006-3020.

Schoop U. D. 2005. The late escape of the neolithic from the central Anatolian plain. In C. Lichter (ed.), How did 
Farming reach Europe? Anatolian-European relations from the second half of the $7^{\text {th }}$ through to the first half of the $6^{\text {th }}$ millennium cal BC. BYZAS Veröffentlichungen des Deutschen Archäologischen Instituts Istanbul 2. Ege Yayınlar1. Istanbul: 41-58.

Sharafi A., Pourmand A., Canuel E. A., Ferer-Tyler E., Peterson L. C., Aichner B., Feakins S. J., Daryaee T., Djamali M., Naderi Beni A., Lahijani H. A. K. and Swart P. K. 2015. Abrupt climate variability since the last deglaciation based on a high-resolution, multi-proxy peat record from NW Iran: The hand that rocked the Cradle of Civilization. Quaternary Science Reviews 123: 215-230.

SRTM (Shuttle Radar Topography Mission) 2017. http:// www2.jpl.nasa.gov/srtm/

Stevens C. J., Fuller D. Q. 2012. Did Neolithic farming fail? The case for a Bronze Age agricultural revolution in the British Isles. Antiquity 86: 707-722.

Sterelny K., Watkins T. 2015. Neolithisation in Southwest Asia in a Context of Niche Construction Theory. Cambridge Archaeological Journal 25(3): 673-705.

Stiner M. C., Buitenhuis H., Duru G., Kuhn S. L., Mentzer S. M., Munro N. D., Pöllath N., Quade J., Tsartsidou G. and Özbaşaran M. 2014. A forager-herder trade-off, from broadspectrum hunting to sheep management at Aşıklı Höyük, Turkey. Proceedings of the National Academy of Sciences of the USA 111: 8404-8409.

Van Andel T. H., Runnels C. N. 1995. The earliest farmers in Europe. Antiquity 69: 481-500.

Weninger B., Jöris 0. 2004. Glacial Radiocarbon Calibration. The CalPal Program. In T. Higham, C. Bronk Ramsey and C. Owen (eds.), Radiocarbon and Archaeology. Fourth International Symposium, Oxford, 2002. Oxford University School of Archaeology. Monograph 62. Oxford: $9-15$.

Weninger B., Jöris 0. 2008. A ${ }^{14} \mathrm{C}$ age calibration curve for the last $60 \mathrm{ka}$ : the Greenland-Hulu U/Th timescale and its impact on understanding the Middle to Upper Paleolithic transition in Western Eurasia. Journal of Human Evolution 55: 772-781.

Weninger B. and 19 co-authors. 2009. The Impact of Rapid Climate Change on prehistoric societies during the Holocene in the Eastern Mediterranean. Documenta Praehistorica 36: 7-59.

Weninger B., Edinborough K., Clare L. and Jöris L. 2011. Concepts of Probability in Radiocarbon Analysis. Documenta Praehistorica 38: 1-20.

Weninger B., Clare L., Gerritsen F., Horejs B., Krauß R., Linstädter J., Özbal R. and Rohling E. J. 2014. Neolithisation of the Aegean and Southeast Europe during the 6600-6000 cal BC period of Rapid Climate Change. Documenta Praehistorica 41: 1-31.

Weninger B., Clare L., Jöris O., Jung R. and Edinborough K. 2015. Quantum theory of radiocarbon calibration. In Special Issue: Prehistoric Bayesian Chronologies (eds. Paul Pettitt and João Zilhão). World Archaeology 47(4): 543566.

Whittle A., Bayliss A. and Healy F. 2008. The Timing and Tempo of Change: Examples from the Fourth Millennium cal. bc in Southern England. Cambridge Archaeological Journal 18(1): 65-70.

Zeder M. A. 2016. Domestication as a model system for niche construction theory. Evolutionary Ecology 30: 325348 .

Zeder M. A., Hesse B. 2000. The initial domestication of goats (Capra hircus) in the Zagros mountains 10,000 years ago. Science 287: 2254-2257.

Zielhofer C., Clare L., Rollefson G., Wächter S., Hoffmeister D., Bareth G., Roettig C., Bullmann H., Schneider B., Berke $H$. and Weninger B. 2012. The decline of the early Neolithic population center of 'Ain Ghazal and corresponding earth-surface processes, Jordan Rift Valley. Quaternary Research 78: 427-441.

\section{back to contents}

